\title{
Studi Faktor Pendukung Popularitas Multiplayer Online Battle Arena dengan Pendekatan Kuantitatif
}

\author{
Tony Wibowo \\ Sistem Informasi, Universitas Internasional Batam, Batam, Indonesia \\ tony.wibowo@uib.ac.id \\ Diterima 15 Februari 2020 \\ Disetujui 09 Juni 2021
}

\begin{abstract}
One of the most popular video game genre nowadays is Multiplayer Online Battle Arena (MOBA). This genre has become the one genre to go in a multiplayer and competitive setting. This study aims to answer what makes this genre become so popular compared to another genre. The quantitative approach was used to gather a consensus of respondents that will give insight to the population's condition. By using Both DeLone \& McLean and UTAUT2 model, it was found that the factors that influence MOBA popularity are Information Quality, Service Quality, Habit, Hedonic Motivation and Social Motivation. These findings show that MOBA usage is still very much influenced by social factor rather than mechanic aspect of video game.
\end{abstract}

Index Terms-DeLone \& McLean; MOBA; UTAUT2

\section{PENDAHULUAN}

Permainan Komputer atau Video Game sebagai media telah mengalami transformasi yang sangat drastis selama hampir 4 dekade terakhir dan telah menjadi salah satu industri hiburan di dunia yang mampu menandingi platform video online dan jaringan televisi dari segi jumlah; dan industri film dan musik dari segi nilai secara finansial [1]-[3]. Sekarang ini bisa dikatakan semua orang didunia ini bermain atau setidaknya pernah bermain video game dalam formatnya yang beragam. Dalam studi sebelumnya disebutkan bahwa adopsi penggunaan smartphone akan disertai dengan adopsi penggunaan video game mobile. Perilaku pemain pada game mobile pun berubah setiap saat sesuai dengan motivasi intrinsik [4]. Banyak penelitian menunjukkan bahwa ada kecenderungan untuk beralih dari platform tradisional video game (PC dan console) menjadi mobile [5].

Multiplayer Online Battle Arena (MOBA) adalah salah satu genre yang paling populer pada video game mobile. Genre ini memiliki karakteristik dimana kita mengendalikan 1 karakter yang dapat dikustomisasi oleh pemain, dan bekerjasama dengan sejumlah pemain lainnya untuk mengalahkan tim lawan dalam sebuah arena yang luas namun tertutup. Setiap pemain mendapat akses terhadap sumber daya yang sama pada awalnya, namun perbedaan pada gaya bermain, kemampuan kerja sama dan penggunaan mekanik dari video game membuat setiap pertandingan adalah pengalaman bermain yang unik [6]. Beberapa game MOBA yang populer antara lain League of Legends (LOL), DOTA 2 dan CS: GO yang ada pada platform tradisional dan Mobile Legend, Vainglory dan Arena of Valor yang ada pada platform mobile [7].

Di Indonesia, video game mulai diakui sebagai industri yang bisa dikatakan cukup terkemuka, inklusi eSport dalam Sea Games 2019 dan pengakuan presiden Joko Widodo mengenai video game sebagai penggerak industri kreatif yang perlu diperhitungkan [8]. Salah satu video game yang paling sering digunakan sebagai barometer eSport adalah League of Legends, sebuah game bergenre MOBA. Ini menjadi katalis popularitas dari game MOBA di tanah air. Penelitian sebelumnya menyebutkan bahwa ada anggota komunitas pemain game Moba di Depok yang menganggap Moba (sebutan populer untuk video game Mobile Legends) tidak hanya sebagai video game semata melainkan kegiatan wajib setiap hari yang juga menjadi sumber pendapatan [9].

Mengapa video game dengan genre MOBA menjadi sangat populer di Indonesia? Penelitian sebelumnya menyebutkan elemen kompetisi pada video game DOTA 2 membuat timbulnya rasa iri antar pemain apalagi ketika dikalahkan, akan muncul rasa penasaran dan tertantang yang membuat pemain kembali bermain [10]. Tantangan tersebut akan menjadi faktor yang mempengaruhi peningkatan penggunaan video game MOBA secara berkala. Aspek kompetitif yang sangat terintegrasi pada mekanik video game MOBA membuat pengguna tidak akan pernah mencapai kepuasan optimal. Pemain lama akan ditantang oleh pemain baru dan bersama-sama meningkat kompetensi dalam video game ini. Kompetisi informal pada video game MOBA ini membuat relevansinya tetap tinggi. Penelitian lain menyebutkan aspek ketidak seimbangan dari video game bergenre MOBA dapat 
mengganggu jalannya permainan dan oleh karena itu menurunkan pengalaman bermain. Mereka juga menyebutkan sekali lagi aspek kompetitif dari video game dengan genre MOBA dan ketimpangan antara pemain veteran dan pemain baru yang mana disebutkan sangat mengganggu sehingga perlu adanya diterapkan sistem match-up yang lebih adil [11]. Kedua penelitian tersebut belum mampu menjawab secara definitif mengapa video game dengan genre MOBA begitu populer di Indonesia secara khususnya dan dunia secara umumnya. Studi ini tertarik untuk mencoba menjawab pertanyaan berikut dengan penelitian yang berjudul "Studi Faktor Pendukung Popularitas Multiplayer Online Battle Arena dengan Pendekatan Kuantitatif'.

\section{TINJAUAN PUSTAKA}

Penelitian ini dilakukan berdasarkan penelitian sebelumnya yang berfokus pada meta-analysis dari penelitian terkait video game bergenre MOBA. Penelitian ini mengidentifikasi artikel yang relevan dari tahun 2011 dan menemukan beberapa temuan yang menarik. Video game League of Legends (LOL) menjadi video game yang paling sering diteliti dalam genre ini. Temuan yang lebih menarik adalah fakta bahwa begitu sedikit artikel penelitian yang membahas video game MOBA. Ini menjadi kesempatan untuk penelitian mendatang untuk berfokus pada bagaimana genre ini dan para pemainnya saling berinteraksi. Salah satu pertanyaan yang belum dijawab adalah bagaimana pengalaman bermain dan perilaku bermain dalam genre ini saling mempengaruhi satu sama lain untuk mendefinisikan model prediksinya [6].

Penelitian berikutnya berfokus pada studi terhadap pengalaman bermain pada game mobile dengan genre MOBA. Penelitian ini adalah penelitian kualitatif dengan menggunakan analisis big data yang berasal dari perilaku pemain dan aspek teknis yang diambil dari salah satu game mobile MOBA terbesar di China. Hasil dari penelitian tersebut menunjukkan bahwa pengalaman bermain tergantung pada dukungan infrastuktur jaringan ketimbang dari konten video game itu sendiri. Pemain yang memiliki koneksi yang baik kendati tidak memiliki kemampuan tehnis bermain video game bisa mengalami kepuasan dan pengalaman bermain yang baik. Namun pada penelitian tersebut tidak bisa menjawab bagaimana perilaku pengguna bisa menjadi parameter yang bisa digunakan untuk mengukur kepuasan bermain [12].

Penelitian berikutnya berfokus pada aspek emosional pemain pada video game bergenre MOBA yaitu League of Legend (LOL). Penelitian ini adalah penelitian kualitatif dengan menggunakan analisis big data yang diambil dari subreddit komunitas pemain game LOL secara global berkumpul dan berinteraksi satu sama lain. Hasil temuan dari penelitian tersebut menunjukkan aspek emosional seperti rasa pencapaian, bangga pada tim bermainnya, kritik pada desain dari game dan identitas sosial sebagai bagian dari komunitas; berhubungan dengan pandangan yang positif terhadap video game meskipun aspek emosional yang dirasakan negatif sekalipun. Hasil penelitian menunjukkan aspek emosional dari pemain video game berbeda dari intepretasi psikologi tradisional dimana aspek emosional tidak selalu dapat diartikan konotasi negatif dan emosi yang ekstrim tidak selalu dapat diartikan menjadi perilaku yang ekstrim pula [13].

Penelitian berikut adalah penelitian kuantitatif mengenai penerimaan terhadap game dengan genre MOBA. Dengan menggunakan model UTAUT2. Dengan berdasarkan data dari 373 responden dan pengujian statistik dengan Structured Equation Modelling (SEM) dengan Partial Least Square (PLS) ditemukan bahwa hampir semua pemodelan UTAUT seperti Performance Expectancy, Effort Expectancy dan Facilitation Condition tidak berpengaruh secara signifikan dalam konteks video game. Malah parameter lainnya yaitu Social Influence, Hedonic Motivation dan Habit menjadi parameter yang berpengaruh. Mereka memberikan rekomendasi berupa model UTAUT yang disederhanakan untuk digunakan pada penelitian selanjutnya [14].

Penelitian berikut berfokus pada pemodelan IS Success Model yang dikembangkan oleh DeLone dan McLean dalam koridor video game. Penelitian dilakukan secara deskriptif dengan menggunakan meta-analysis dari penelitian sebelumnya. Hasil penelitian mereka adalah model IS Success Model dengan modifikasi dimensi pada konstruk penelitian untuk digunakan pada kesuksesan video game. Mereka juga menyebutkan bahwa dari sudut pandang holistik, alasan mengapa beberapa video game lebih sukses dari yang lain belum terjawab secara definitif dan perlu dilakukan penelitian selanjutnya untuk memberikan pengetahuan yang lebih konkrit terkait cabang ilmu ini [15].

Dari kelima penelitian tersebut, peneliti berusaha menjawab tantangan dari akhir penelitian [6] mengenai perlunya penelitian lebih lanjut mengenai video game berbasis MOBA. Secara spesifik studi ini berusaha menarik kesimpulan dari bagaimana genre MOBA menjadi sangat populer. Penelitian ini juga mencoba menjawab hal yang tidak bisa dijawab pada penelitian [12] terkait hubungan perilaku pengguna dengan pengalaman bermain dan mengkonfirmasi temuan pada penelitian [13] terkait aspek emosional dari pemain khususnya pada genre MOBA. Didalam studi ini juga mencoba untuk menkonfirmasi pemodelan kesuksesan video game yang disampaikan oleh [15] yang berdasakan IS Success Model. Dan terakhir, melalui penelitian ini juga hendak menguji ulang temuan dari penelitian [14] yang menggunakan model UTAUT sebagai dasar penelitian. 


\section{Metodologi PENELITIAN}

Penelitian ini adalah penelitian kuantitatif dimana penelitian ini akan menjawab masalah penelitian dengan pembuktian seara statistik [16]. Metode yang digunakan adalah closed questionnaire yang pertanyaan ditujukan untuk mengetahui faktor popularitas game MOBA dari segi elemen video game maupun elemen sosial pada video game tersebut. Populasi dari penelitian ini adalah masyarakat yang pernah atau sedang bermain game MOBA secara aktif dari usia 15-35 tahun. Populasi ini dipilih sesuai dengan laporan [17] yang menyebutkan segmen masyarakat tersebut adalah segment dengan penetrasi video game tertinggi yaitu hampir $60.2 \%$. Perhitungan sampel yang dibutuhkan akan menggunakan rumus Slovin. Secara umum penelitian akan dilakukan sesuai alur pada Gambar 1.

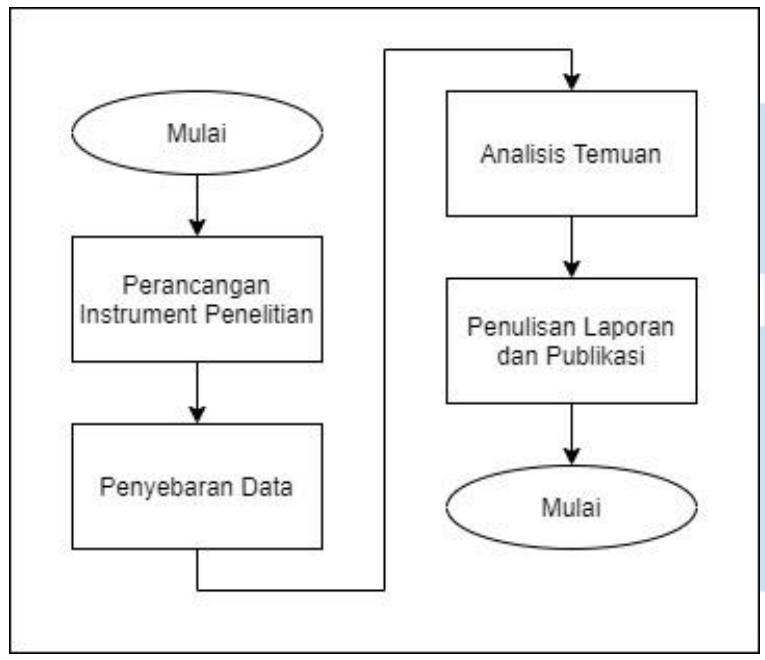

Gambar 1. Alur penelitian

Penelitian dilakukan dengan merancang instrumen penelitian sesuai dengan model penelitian IS Success Model dari DeLone dan McLean [15], [18] dan UTAUT2 [14], [19] (lihat Gambar 2 dan Gambar 3). Semua pertanyaaan dibuat dalam bentuk kuesioner dengan menggunakan skala Likert. Hasil analisis akan ditampilkan dalam bentuk relasi regresi yang dihasilkan dari kedua model.

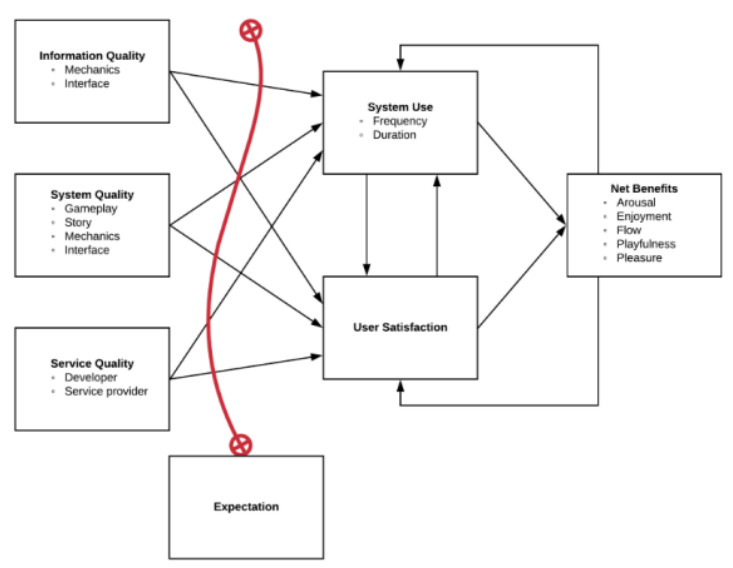

Gambar 2. Model DeLone dan McLean

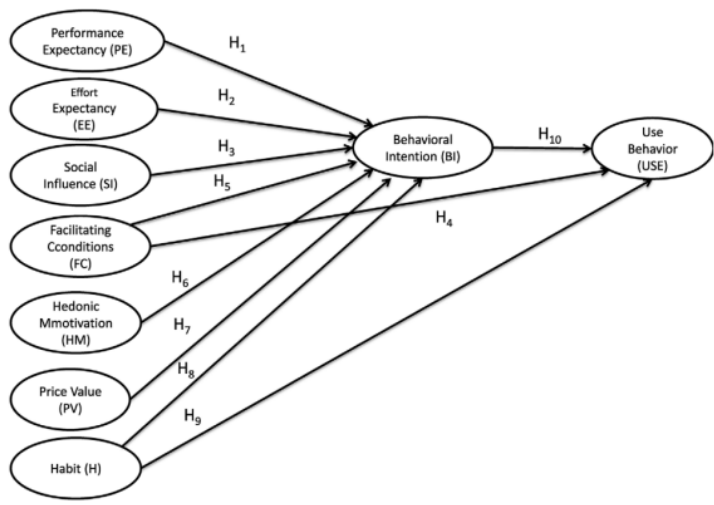

Gambar 3. Model UTAUT 2

Pertanyaan yang akan dimasukkan kedalam instrumen penelitian ditunjukkan pada Tabel 1.

Tabel 1. Pertanyaan kuesioner

\begin{tabular}{|l|l|}
\hline \multicolumn{2}{|l|}{ Performance Expectation (PE) } \\
\hline PE1 & Saya merasa bermain MOBA berguna bagi saya \\
\hline PE2 & $\begin{array}{l}\text { Saya merasa ketika bermain MOBA meningkatkan } \\
\text { kesempatan saya mencapai hal yang saya inginkan }\end{array}$ \\
\hline PE3 & $\begin{array}{l}\text { Ketika bermain MOBA, saya termotivasi untuk } \\
\text { menyelesaikan pekerjaan saya lebih cepat }\end{array}$ \\
\hline PE4 & $\begin{array}{l}\text { Bermain MOBA membuat produktivitas saya } \\
\text { meningkat }\end{array}$ \\
\hline Effort Expectation (EE) \\
\hline EE1 & $\begin{array}{l}\text { Mempelajari cara bermain MOBA gampang buat } \\
\text { saya }\end{array}$ \\
\hline EE2 & $\begin{array}{l}\text { User interface pada game MOBA jelas dan mudah } \\
\text { dipahami }\end{array}$ \\
\hline EE3 & Saya merasa MOBA bisa dimainkan dengan mudah \\
\hline EE4 & $\begin{array}{l}\text { Saya bisa dengan cepat menjadi ahli di game } \\
\text { MOBA }\end{array}$ \\
\hline Social Influence (SI) \\
\hline SI1 & $\begin{array}{l}\text { Teman-teman saya merasa saya perlu bermain } \\
\text { MOBA }\end{array}$ \\
\hline SI2 & Keluarga saya mendukung saya bermain MOBA \\
\hline SI3 & $\begin{array}{l}\text { Pacar/pasangan saya mendukung saya bermain } \\
\text { MOBA }\end{array}$ \\
\hline SI4 & Banyak teman-teman saya juga bermain MOBA \\
\hline
\end{tabular}

Ultima InfoSys : Jurnal Ilmu Sistem Informasi, Vol. 12, No. 1 | Juni 2021 


\begin{tabular}{|c|c|c|c|}
\hline \multirow[t]{2}{*}{ SI5 } & \multirow{2}{*}{$\begin{array}{l}\text { Teman dekat saya sering bermain MOBA dengan } \\
\text { saya }\end{array}$} & \multirow{3}{*}{ USE3 } & untuk bermain MOBA \\
\hline & & & \multirow{2}{*}{$\begin{array}{l}\text { Saya akan bermain MOBA di masa yang akan } \\
\text { datang }\end{array}$} \\
\hline \multicolumn{2}{|c|}{ Facilitating Condition (FC) } & & \\
\hline FC1 & $\begin{array}{l}\text { Saya memiliki handphone yang cukup kuat untuk } \\
\text { memainkan MOBA dengan lancar }\end{array}$ & USE4 & $\begin{array}{l}\text { Saya berencana untuk bermain MOBA pada } \\
\text { minggu ini }\end{array}$ \\
\hline
\end{tabular}

Uji regresi yang dilakukan pada kedua model akan diproses dengan aplikasi SPSS, yang mana versi yang digunakan dalam penelitian ini adalah versi 22 .

\section{HASIL DAN PEMBAHASAN}

Responden yang digunakan dalam penelitian ini sebanyak 376 responden. Jumlah ini memenuhi jumlah sampel yang disarankan sesuai dengan rumus Slovin yaitu sebesar 377 untuk populasi $>20.000$ dan margin error 5\%. 82,2\% atau 309 responden adalah laki-laki dan $17,8 \%$ atau 67 responden adalah perempuan. Mayoritas responden dengan persentasi $76,6 \%$ atau 288 responden adalah umur 18-25 tahun dengan $64,6 \%$ atau 243 responden adalah pelajar dan mahasiswa diikuti oleh $32,2 \%$ atau 121 responden adalah wirausaha atau entrepreneur. $64,6 \%$ atau 243 responden berasal dari wilayah sumatera dan $32,2 \%$ atau 121 berasal dari wilayah jawa dan sisanya $3 \%$ atau 12 responden dari wilayah Kalimantan dan Sulawesi. 50,3\% atau 189 responden mengaku bermain MOBA dibawah 2 jam diikuti $35,1 \%$ atau 132 responden bermain MOBA selama 2-4 jam dan 14,6\% atau 55 responden bermain lebih dari 4 jam dengan $43,1 \%$ adalah pemain aktif yang bermain setiap hari. Platform pilihan pemain adalah sebesar $69,7 \%$ atau 262 responden bermain di platform mobile atau smartphone.

Untuk game dengan genre MOBA yang paling sering dimainkan. 323 responden atau $85,90 \%$ menyebutkan Mobile Legend Bang Bang. Hasil ini sudah diprediksi sebelumnya dan sesuai dengan penelitian sebelumnya yang mendiskusikan genre sejenis [7], [9], [10]. 48,67\% atau 183 responden juga menyebutkan bahwa DOTA 2 adalah game MOBA yang sering dimainkan. Sedangkan League of Legends salah satu game MOBA terbesar di dunia hanya berada di posisi 5 dibawah DOTA 1 dan Arena of Valor.

Untuk menguji data yang diperoleh terlebih dahulu dilakukan pengujian kualitas data dengan menggunakan uji korelasi Pearson Product sebagai uji validitas setiap indikator instrumen penelitian. Hasil dari uji validitas pada setiap indikator menunjukkan bahwa semua indikator memiliki nilai signifikansi pada koefisien korelasi Pearson dibawah 0,005 sehingga dapat disimpulkan bahwa seluruh indikator pada instrument penelitian adalah valid. Selanjutnya dilakukan uji reliabilitas data dengan menggunakan uji reliabilitas dengan Cronbach's Alpha. Konstruk penelitian yang reliabel sebaiknya memenuhi standar Cronbach's Alpha diatas sama dengan 0,7 [20]. Dari hasil uji reliabilitas seluruh konstruk mendapatkan 
hasil diatas sama dengan 0,7 dengan demikian dapat disimpulkan seluruh kontruk penelitian adalah valid.

Uji regresi dilakukan sebanyak 2 kali dengan menggunakan 2 model: Delone dan McLean dan UTAUT2. Hasil dari uji regresi pertama menghasilkan 2 konstruk memiliki pengaruh yang dominan dalam popularitas moba yaitu Information Quality (IQ) dan Service Quality (ServQ), keduanya memiliki nilai signifikansi 0.000 dengan nilai $B$ sebesar 0,464 untuk IQ dan 0.465 (ServQ). Model regresi ini memiliki nilai uji $F$ sebesar 78,546 dengan $p$-value 0,000 , nilai Durbin-Watson sebesar 1.834 dan Adjusted $R^{2}$ sebesar 0,383 menunjukkan model ini memiliki hubungan yang signifikan secara statistik, tidak memiliki hubungan autokorelasi antar variabel independent dan menjelaskan 38,3\% dari total variabiltas. Persamaan regresi dari model DeLone dan McLean ditunjukkan pada (1).

$$
\mathrm{USE}=-1.019+0.464 \mathrm{IQ}+0.151 \mathrm{SQ}+0.465 \mathrm{ServQ}
$$

Uji regresi dengan model UTAUT 2 menunjukkan terdapat 3 konstruk utama yang menjadi faktor popularitas dari game MOBA di Indonesia. Yang pertama dan paling mendominasi adalah faktor Habit atau kebiasaan dilanjutkan Hedonic Motivation atau motivasi hedonis dan Social Influence atau pengaruh sosial. Dan 2 kontruk yang paling tidak berpengaruh adalah Effort Expectancy atau harapan atas usaha yang dikeluarkan dan Price atau harga. Model regresi ini memiliki nilai uji $F$ sebesar 89,677 dengan $p$-value 0,000, nilai Durbin-Watson sebesar 1,906 dan adjusted $R^{2}$ sebesar 0,623 menunjukkan model ini juga memiliki hubungan yang signifikan secara statistik, tidak memiliki hubungan autokorelasi antar variabel independent dan menjelaskan $62,3 \%$ dari total variabiltas. Persamaan regresi dari model UTAUT2 dapat dilhat pada (2).

$$
\begin{gathered}
\mathrm{USE}=-0.323+0.75 \mathrm{PR}+0.002 \mathrm{EE}+0.2 \mathrm{SI}+ \\
0.036 \mathrm{FC}+0.267 \mathrm{HE}-0.004 \mathrm{PR}+0.504 \mathrm{HA}
\end{gathered}
$$

Dari kedua hasil uji regresi pada kedua model menunjukkan hal yang sangat menarik, terutama dalam mendeskripsikan pemain genre MOBA di Indonesia. Salah satu hal yang sangat kentara seperti ditunjukkan pada model DeLone dan McLean. Konstruk IQ yang lebih tinggi dari SQ dalam kasus game dengan genre MOBA, pemain lebih memberikan nilai pada mekanik game dan interface dari game ketimbang grafis dan cerita. Apabila kita melakukan observasi pada perilaku pemain MOBA cenderung tidak lagi membaca cerita atau lore dari setiap karakter namun berfokus pada bagaimana mekanik penggunaan sebuah karakter dalam cakupan genre MOBA. Misalnya saja pada video game Mobile Legends Bang Bang, inklusi karakter "Gatot Kaca" secara konsep cerita adalah sesuatu yang konyol namun pemain tidak begitu peduli dan lebih mementingkan cara menggunakan karakter tersebut. Variabel yang juga memiliki pengaruh yang besar adalah layanan yang baik dari pengembang terutama layanan terkait masalah yang ditemui juga menjadi salah satu faktor populernya genre MOBA dikalangan pemain.

Menurut model UTAUT 2, yang juga menghasilkan temuan yang menarik adalah menjelaskan mengapa MOBA begitu terkenal dikalangan milenial dan generasi $\mathrm{Z}$ di Indonesia. Faktor kebiasaan menjadi salah satu faktor yang sangat dominan dan menjadi salah satu sebab mengapa "game online" memiliki konsepsi yang jelek di mata guru dan orang tua karena pelajar memiliki kecanduan dengan game online. Dengan meningkatnya teknologi mobile dan semakin mudah diaksesnya smartphone dan teknologi infrastruktur yang semakin baik, "game online" beralih ke "mobile gaming". Seperti pada awal tahun 2000-an dimana semua warnet adalah bermain game online dan multiplayer (termasuk didalamnya Counter Strike dan DOTA 1), kebiasaan itu berlanjut pada era mobile gaming dan game multiplayer yang paling populer dari zaman PC ke Mobile adalah genre MOBA dan FPS. Ini adalah transisi yang logis dan menjadi dinding yang sulit ditembus oleh genre lainnya. Mobile Legends Bang Bang menjadi yang paling populer karena menjadi salah satu game dengan genre MOBA pertama yang tersedia di platform mobile. Pada model yang sama menyebutkan bahwa salah satu faktor yang mempengaruhi adalah pengaruh sosial. Semakin meningkatnya popularitas dan genre MOBA apalagi genre ini dirancang untuk lebih optimal dimainkan bersama orang lain. Istilah "mabar" atau main bareng pada konteks mobile gaming mayoritas didefinisikan menjadi bermain MOBA bersama-sama.

Faktor yang juga mendukung adalah motivasi hedonis. Ini menunjukkan bahwa video game secara umum bertujuan sebagai faktor hiburan dan hampir tidak ada maksud lain dari video game, terutama genre MOBA. Tingginya faktor ini tidak diturunkan oleh faktor kompetitif dari genre MOBA, dengan artian kalah adalah bagian dari kesenangan tersendiri dalam genre MOBA. Permainan yang dilakukan antar pemain yang saling mengenal akan meningkatkan motivasi hedonis. Tingginya investasi waktu yang dilakukan pada video game dengan genre MOBA membuat setiap kekalahan dan kemenangan adalah sesuatu yang perlu dirayakan. Inilah mengapa faktor Effort Expectancy atau harapan atas usaha yang dikeluarkan sangat tidak relevan pada popularitas MOBA. Seorang pemain genre MOBA bisa menghabiskan ratusan jam untuk menjadi ahli dalam game ini. Investasi waktu tersebut tidak menggambarkan motivasi karir, karena tidak semua akan menjadi atlit e-sport. Jumlah investasi usaha yang dilakukan tersebut hanya untuk digunakan untuk memuaskan motivasi hedonis. Harga selalu akan menjadi faktor bagi pemain di Indonesia yang memiliki masalah budaya pembajakan video game 
yang besar, namun tidak sebesar itu dalam kasus genre MOBA. Beberapa pemain yang serius menghabiskan uang dalam cukup banyak secara rutin untuk tetap relevan sebagai pemain meski pengeluarannya murni untuk nilai kosmetik belaka dan tidak memberikan keuntungan dalam bermain.

Dari kedua model, terdapat sebuah kesamaan yang menarik. Kedua model memiliki posisi negatif pada konstanta model regresinya. Hal ini menunjukkan bahwa pemain game memulai dengan adalah perasaan negatif terhadap genre MOBA. Video game secara umum adalah sesuatu yang dinilai untuk anak-anak untuk budaya orang Indonesia. Indonesia tidak seperti negara seperti Korea Selatan, Jepang dan Amerika yang menganggap video game sebagai sesuatu yang serius. E-sport sebagai olahraga saja adalah sesuatu yang agak sulit diterima bagi penikmat olahraga meski catur sebagai cabang olahraga meja yang klasik juga mendapatkan perlakuan yang sama. Tidak semua orang bisa menikmati game MOBA seperti menikmati speak bola. Setiap karakter dalam game MOBA adalah unik dengan mekanik yang sangat berbeda. Untuk menikmati MOBA anda harus memiliki pengetahuan yang cukup mengenai MOBA karena jika tidak animasi dan pergerakan di genre MOBA bisa membuat penonton awam pusing.

\section{SimPULAN}

Penelitian ini berfokus pada menjawab faktor yang menjadi alasan mengapa genre MOBA sangat populer di Indonesia. Dengan menggunakan model DeLone dan McLean dan UTAUT, penelitian kuantitatif ini mengumpulkan dan menganalisis data dari 376 responden. Hasil yang didapatkan menunjukkan menurut model DeLone dan McLean, faktor yang berpengaruh adalah Information Quality (mekanik dan interface) dan Service Quality (developer dan service provider). Sedangkan pada model UTAUT2, faktor yang berpengaruh adalah Habit, Hedonic Motivation dan Social Influence. Hasil ini sesuai dengan hasil penelitian [14], [15] yang mana menjadi validasi dari hasil penelitian sebelumnya. Hasil penelitian ini juga memberikan salah satu bukti empiris bagaimana perilaku pengguna menjadi faktor kepuasan dalam bermain video game, dengan dibuktikan dengan bagaimana kebiasaan menjadi faktor yang berpengaruh dalam pandangan yang postif terhadap video game MOBA.

Temuan ini menjadi hasil dari tujuan penelitian ini mengenai faktor popularitas video game dengan genre MOBA secara empiris. Hasil dari penelitian ini diharapkan dapat menjadi masukan bagi pengembang video game atas persepsi dari pemain game Indonesia dan masukan bagi stakeholder pemain game terkait (orang tua, pendidik, pemerintah) bagaimana pemain video game modern beralih dari game online menjadi mobile gaming. Pengembangan video game selanjutnya bisa mempertimbangkan faktor kebiasaan yang terbukti menjadi faktor yang membuat MOBA populer. Penelitian berikut bisa berfokus pada bagaimana cara membangun kebiasaan dalam video game dan bagaimana hubungannya dengan kecanduan video game. Mengenai faktor motivasi hedonis yang menjadi salah satu faktor dominan populernya MOBA akan menjadi salah satu titik yang menarik untuk penelitian berikutnya dalam mengukur bagaimana rasa senang dari bermain game berasal. Video game di Indonesia mengalami peningkatan yang luar biasa dan isu ini menjadi penting karena sudah banyak sekali penelitian sebelumnya yang menyebutkan bagaimana teknologi mempengaruhi perilaku manusia, video game akan menjadi faktor yang akan sangat berpengaruh dimasa yang akan datang.

\section{UCAPAN TERIMA KASIH}

Peneliti mengucapkan terima kasih kepada Dr. Hendi Sama, Deli Tan dan Herman untuk diskusi yang menarik mengenai studi ini.

\section{DAFTAR PUSTAKA}

[1] J. A. Fox, “'It's a-me, Mario!'Exploring dynamic changes and similarities in the composition of early Nintendo video game music," Fields J. Huddersf. student Res., vol. 2, no. 1, pp. 15-30, 2016.

[2] A. Gupta, A. Gupta, S. Nicovich, S. Nicovich, T. Garrison, and T. Garrison, "Electronic Arts: gambling on the future of video games," Emerald Emerg. Mark. Case Stud., vol. 6, no. 2, pp. 1-20, 2016.

[3] J. Shi, M. N. Potenza, and N. E. Turner, "Commentary on: 'The Future of Gaming Disorder Research and Player Protection: What Role Should the Video Gaming Industry and Researchers Play?,"' Int. J. Ment. Health Addict., vol. 18, no. 3, pp. 791-799, 2020.

[4] O. Lopez-Fernandez, N. Männikkö, M. Kääriäinen, M. D. Griffiths, and D. J. Kuss, "Mobile gaming and problematic smartphone use: A comparative study between Belgium and Finland,” J. Behav. Addict., vol. 7, no. 1, pp. 88-99, 2018.

[5] C. S. Chen, H. P. Lu, and T. Luor, "A new flow of Location Based Service mobile games: Non-stickiness on Pokémon Go," Comput. Human Behav., vol. 89, pp. 182-190, 2018.

[6] M. Mora-Cantallops and M. Á. Sicilia, "MOBA games: A literature review," Entertain. Comput., vol. 26, no. February, pp. 128-138, 2018.

[7] R. T. Pantouw and D. T. H. Aruan, "Influence of Game Design and Playability Toward Continuance Intention Using TAM Framework," IPTEK J. Proc. Ser., vol. 0, no. 5, p. 307, 2019

[8] N. Laksamana, "Turunkan 21 Atlet, Tim Esports Indonesia Bertekad Sabet Medali SEA Games 2019," Kompas Bola, 03 Dec-2019.

[9] S. A. Sunarto, C. Wulandari, and E. Hartanto, "Communication Meaning in The Community Online Mobile Legends Based on Depok Players Realities," Int. J. Multicult. Multireligious Underst., vol. 6, no. 4, pp. 43-48, 2019.

[10] R. Soleh, R. I. Rokhmawati, and K. C. Brata, "Analisis Pengalaman Pengguna Permainan Multiplayer Online Battle Arena ( Moba ) Dengan Menggunakan Game Experience Questionnaire ( GEQ ) Pada Game Dota 2," J. Pengemb. Teknol. Inf. dan Ilmu Komput., vol. 2, no. 9, pp. 3067-3076, 2018.

[11] M. L. Adhitama, E. M. A. Jonemaro, and W. S. Wardhono, "Evaluasi User Experience Gim Defense of The Ancients 2 (DOTA 2) menggunakan Metode Flow Framework," $J$. 
Pengemb. Teknol. Inf. dan Ilmu Komput., vol. 4, no. 1, pp 17-24, 2020.

[12] C. Mo, Z. Wang, G. Zhu, and W. Zhu, "Understanding Gaming Experience in Mobile Multiplayer Online Battle Arena Games," Proc. 28th ACM Work. Netw. Oper. Syst. Support Digit. Audio Video, NOSSDAV 2018, pp. 25-30, 2018.

[13] Y. Kou and X. Gui, "Emotion Regulation in Esports Gaming. a Qualitative Study of League of Legends," Proc. ACM Human-Computer Interact., no. October, 2020.

[14] P. Ramírez-Correa, F. J. Rondán-Cataluña, J. Arenas-Gaitán, and F. Martín-Velicia, "Analysing the acceptation of online games in mobile devices: An application of UTAUT2," J. Retail. Consum. Serv., vol. 50, no. December 2018, pp. 8593, 2019.

[15] B. Hanus and B. George, "A Hedonic System Perspective of the Delone and McLean IS Success Model," AMCIS 2020
Proc., pp. 0-10, 2020

[16] J. W. C. N.-M. H. L.-S. L. H. C. Creswell, Research design: Qualitative, quantitative, and mixed methods approaches. Sage Publication, 2013

[17] S. Kemp, "Digital 2021: Indonesia," 2021.

[18] F. Pai and K. Huang, "Applying the Technology Acceptance Model to the introduction of healthcare information systems," Technol. Forecast. Soc. Change, vol. 78, no. 4, pp. 650-660, 2011

[19] V. Venkatesh, J. Y. L. Thong, and X. Xu, "Consumer acceptance and use of information technology: extending the unified theory of acceptance and use of technology," MIS $Q$., vol. 36, no. 1, pp. 157-178, 2012.

[20] J. F. Hair Jr, C. William, B. J. Babin, and R. E. Anderson, on Multivariate Data Analysis Joseph F . Hair Jr. William C. Black Seventh Edition. Edinburg: Pearson, 2014. 